\title{
Regulation mechanism of Fbxw7-related signaling pathways (Review)
}

\author{
ZHENYU ZHOU, CHUANCHAO HE and JIE WANG \\ Department of Hepatobiliary Surgery, Sun Yat-sen Memorial Hospital, \\ Sun Yat-sen University, Guangzhou, Guangdong 510120, P.R. China
}

Received February 25, 2015; Accepted May 29, 2015

DOI: $10.3892 /$ or.2015.4227

\begin{abstract}
F-box and WD repeat domain-containing 7 (Fbxw7), the substrate-recognition component of SCFF ${ }^{\text {bxw7 }}$ complex, is thought to be a tumor suppressor involved in cell growth, proliferation, differentiation and survival. Although an increasing number of ubiquitin substrates of Fbxw7 have been identified, the best characterized substrates are cyclin $\mathrm{E}$ and c-Myc. Fbxw7/cyclin E and Fbxw7/c-Myc pathways are tightly regulated by multiple regulators. Fbxw7 has been identified as a tumor suppressor in hepatocellular carcinoma. This review focused on the regulation of Fbxw7/cyclin E and Fbxw7/c-Myc pathways and discussed findings to gain a better understanding of the role of Fbxw7 in hepatocellular carcinoma.
\end{abstract}

\section{Contents}

1. Introduction

2. Fbxw7 and the mechanism of degradation of its substrates

3. Regulation of Fbxw7-cyclin E/c-Myc signaling pathways

4. Role of Fbxw7 in hepatocellular carcinoma

5. Conclusions

Correspondence to: Professor Jie Wang, Department of Hepatobiliary Surgery, Sun Yat-sen Memorial Hospital, Sun Yat-sen University, 107 Yan-Jiang Xi Road, Guangzhou, Guangdong 510120, P.R. China

E-mail: sumsjw@163.com

Abbreviations: Fbxw7, F-box and WD repeat domain-containing 7; HCC, hepatocellular carcinoma; UPS, ubiquitin-proteasome system; EMT, epithelial-mesenchymal transition; E1, ubiquitin-activating enzyme; E2, ubiquitin-conjugating enzyme; E3, ubiquitin ligases; SKP1, S-phase kinase-associated protein 1; CUL1, cullin 1; RBX1, RING box 1; mTOR, mammalian target of rapamycin; CPD, Cdc4 phosphodegron; GSK3, glycogen synthase kinase 3; NPM, nucleolar protein nucleophosmin; PIK2, Polo-like kinase 2; bHLH, basic helix-loop-helix; bHLH/Zip, basic helix-loop-helix zipper; PP2A, protein phosphatase $2 \mathrm{~A}$; BLM, bloom; NEMO, NF- $\mathrm{BB}$ essential modulator; $\mathrm{CSN}$, COP9 signalosome

Key words: cancer, tumor suppressor, Fbxw7, cyclin E, c-Myc, hepatocellular carcinoma

\section{Introduction}

Cancer is considered a terrible disease that leads to a global health threat. Although significant improvements have been made in the management of cancer as well as the comprehension of the molecular mechanisms of neoplasm pathogenesis and progression, cancer remains a common disorder worldwide, accounting for 12.7 million new cancer cases and 7.6 million cancer deaths in 2008, worldwide $(1,2)$. Previous findings have shown that tumorigenesis in humans is a multistep process foundational with mutations which can activate oncogenes and inactivate tumor-suppressor genes. The genetic alterations can result in changes of the proteome, and these changes eventually drive the malignant biological behavior through complex signaling pathways (3-9).

The ubiquitin-proteasome system (UPS), which is responsible for the degradation of $>80 \%$ of cell proteins, is the main proteolytic mechanisms involved in eukaryocytes $(3,4)$. Most of the proteins involved in cell cycle progression, proliferation and apoptosis are regulated by the UPS (5). Dysregulation of the UPS may contribute to tumor progression, drug resistance and altered immune surveillance (5). Previous studies have focused on the relationship between epithelial-mesenchymal transition (EMT) signal transduction pathways and UPS, and found that many signal transducers and transcription factors involved in EMT are regulated by ubiquitination and the UPS (6). It is well-known that the UPS consists of three classes of enzymes: the ubiquitin-activating enzyme (E1), the ubiquitin-conjugating enzyme (E2) and ubiquitin ligases (E3). In most cases, the three enzymes together with $26 \mathrm{~S}$ proteasome drive target substrate degradation through a series of catalytic processes $(5,7)$. In the human genome there are two E1s, $\sim 30-40$ E2s and $>600$ E3 ligases (8). It should be emphasized that during the ubiquitination, E3 mediates the transfer of ubiquitin from E2 to the substrate protein. Thus, it has a central role in the substrate decision (9).

The SCF complexes belong to the cullin-RING ligase family and are the largest family of E3 ligases comprising four subunits: S-phase kinase-associated protein 1 (SKP1), which is responsible for recruiting the variable F-box protein; cullin 1 (CUL1), which provides a rigid scaffold connecting SKP1 and RBX1 on opposite ends; RING box 1 (RBX1; also known as ROC1 or HRT1), which serves as an interface for E2 ubiquitin-conjugating enzymes; and a member of the F-box 
protein family, which functions as a substrate-recognition component $(10,11)$. F-box and WD repeat domain-containing 7 (Fbxw7; also known as Fbw7, hCdc4, hAGO and Sel10) is an evolutionarily conserved protein belonging to the F-box family. It was first identified as Cdc4 in budding yeast in 1973 (12). Sel10 was subsequently identified in Caenorhabditis elegans as a negative regulator of Lin-12 (homology of Notch) (13). In parallel, archipelago, a gene in Drosophila melanogaster encoding a protein containing an F-box domain and seven tandem WD repeats (AGO) domain, was identified (14). From those studies, the human homologue was ascertained and was designated as Fbxw7 or Fbw7.

Fbxw7 is thought to be a tumor suppressor involved in cell growth, proliferation, differentiation and survival (15). Fbxw7 has been found to be inactivated by mutation in various human cancer types (16-18). Fbxw7 has an unusual mutation spectrum whereby biallelic, simple loss-of-function mutations are rare. Instead, most mutations are monoallelic missense changes involving specific arginine residues at $\beta$-sheet propellor tips that allow the Fbxw7 protein to recognize its substrates (19). Inactivation of the Fbxw7 protein is associated with the deregulation of several well-known oncoproteins with significant capabilities in pathways that manage cell division and growth, including cyclin E (20), c-Myc (21), c-Jun (22), Notch (23), Mcl-1 (24) and mammalian target of rapamycin (mTOR) (25) (Table I).

Therefore, the dysregulation of Fbxw7-mediated proteasome degradation is likely involved in many signaling pathways which play important roles in human cancers. Among these oncogenic Fbxw7 substrates, cyclin E and c-Myc may be the most clearly investigated oncoproteins that have certain contributions to Fbxw7-associated cancers. In this review, we discuss the two major signaling pathways impacted by Fbxw7 to show how Fbxw7-related signaling pathways are regulated in cancer. In addition, since few studies have focused on the relationship between hepatocellular carcinoma (HCC) and Fbxw7, we assess molecular mechanisms by which Fbxw7 exerts antitumor activity in HCC.

\section{Fbxw7 and the mechanism of degradation of its substrates}

Fbxw7, which shares the WD40 repeats structure (a substrate interaction domain used to classify F-box proteins), is a well-studied member of the F-box family (54). The human FBXW7 gene consists of 4 introns and 13 exons and its gene locus maps to chromosome region $4 \mathrm{q} 32$, which is commonly deleted in many types of human malignancies $(17,55)$. The $F B X W 7$ gene encodes the Fbxw $7 \alpha$, Fbxw $7 \beta$ and Fbxw $7 \gamma$ protein isoforms, which have distinct subcellular localizations, with Fbxw $7 \alpha$ mainly localizing to nucleoplasm, Fbxw $7 \beta$ to cytoplasm and Fbxw7 $\gamma$ to nucleolus (56). The three isoforms also seem to have tissue specificity with the $\alpha$-form being found to be extensively expressed in human tissues, while the $\beta$-form and/or $\gamma$-form are present at lower levels, except in skeletal muscle, brain and to a lesser degree, heart (17).

In addition to the $\mathrm{N}$-terminal region which contains dominant signals for the subcellular localization, each isoform of Fbxw7 shares conserved interaction domains in the C-terminal region: the eight WD40 repeats that determine target specificity; the F-box that recruits the SKP1 of the
SCF complex; and the D domain that dimerize the $\mathrm{SCF}^{\mathrm{Fbxw}}$, which allows it to target substrates with low-affinity $\mathrm{Cdc} 4$ phosphodegron (CPDs) (15). All these domains are essential for the degradation of its substrates.

Although the three Fbxw7 isoforms share many identical functional domains, recent studies have identified that each isoform has its special function. The $\alpha$-form is most abundant and accounts for degradation of most tested substrates. Fbxw $7 \beta$ is proved to reside in the endoplasmic reticulum membrane and protects cells from oxidative stress (57). Moreover, Fbxw $7 \alpha$ and Fbxw7 $\beta$ are found to play an opposite role in their substrates. For example, PGC-1 $\alpha$, a transcriptional coactivator with broad effects on cellular energy metabolism, is found to have a different fate under different Fbxw7 isoforms (52). Fbw $7 \beta$ reduces cellular PGC- $1 \alpha$ via ubiquitin-mediated degradation, whereas Fbw $7 \alpha$ increases cellular PGC-1 $\alpha$ via ubiquitin-mediated stabilization (52).

Evidence suggests that substrates of Fbxw7 are polyubiquitinated in a GSK3-dependent manner by $\operatorname{SCF}^{\mathrm{Fbxw} 7}(22,33,58)$. Glycogen synthase kinase 3 (GSK3), firstly identified in 1980, is a constitutively active and ubiquitously expressed serine/threonine kinase $(59,60)$. Human cells contain two GSK3 isoforms, known as GSK $3 \alpha$ and GSK3 $\beta$, which are highly similar with respect to sequence (share $97 \%$ amino acid sequence within their catalytic domains) and function (61). The activation of GSK3 is dominated by phosphorylation on Ser-21 of GSK3 $\alpha$ and Ser-9 of GSK3$\beta$ (62). It is well established that these phosphorylations are regulated via PI3K/Akt pathway (63). In most cases, inactivation of the PI3K/Akt pathway leads to dephosphorylation of GSK3, which results in the activation of GSK3. The activated GSK3 subsequently phosphorylates the CPDs of the substrates that are primed by phosphorylation at position +4 of the CPD by a yet to-be-identified kinase (in the cyclin E case, which is Cdk2) $(33,64)$. The CPDs of substrates are recognized and interacted with the eight WD40 repeats of Fbxw7 for ubiquitin-mediated proteolytic degradation (65).

CPD is a phosphodegron motif existing in the substrates of Fbxw7. The phosphorylation of CPD by GSK3 is crucial for the interaction between Fbxw7 and its substrate. Mutation of critical residues within the CPD lead to stabilization of substrates, such as c-Myc and has been observed in many human cancers (66). Data gathering from Fbxw7 substrates have ascertained the conserved CDP sequence as ФХФФФ-T/ S-PPX-S/T/E, with $\Phi$ standing for a hydrophobic residue and $X$ for any amino acid $(65,67)$. The $T / S$ residue can be phosphorylated by GSK3 and the phosphorylation of S/T/E residue serves as a priming signal for GSK3 phosphorylation. Moreover, studies also found that some substrates have more than one CPD. For example, studies have revealed that cyclin E has two CPDs, with one located in the T380 and the other one being centered at $\sim$ T62 $(68,69)$. The two CPDs of cyclin E were essential for efficiency of Fbxw7 binding, in response to different signaling pathways (70).

\section{Regulation of Fbxw7-cyclin E/c-Myc signaling pathways}

Over the past decade, a number of studies have contributed to the understanding of Fbxw7 molecular mechanisms in human cancers. Several molecules that play an essential role in tumor pathogenesis and progression have been identified to 
Table I. Substrates of Fbxw7.

\begin{tabular}{|c|c|c|}
\hline Protein name & Full name & Ref. \\
\hline Cyclin E & - & 20 \\
\hline c-Myc & - & 21 \\
\hline c-Jun & - & 22 \\
\hline Notch & - & 23 \\
\hline Mcl-1 & Myeloid cell leukemia 1 & 24 \\
\hline mTOR & Mammalian target of rapamycin & 25 \\
\hline PS 1 & Presenilin 1 & 26 \\
\hline N-Myc & - & 27 \\
\hline p63 & - & 28 \\
\hline c-Myb & - & 29 \\
\hline $\mathrm{HIF}-1 \alpha$ & Hypoxia-inducible transcription factor- $1 \alpha$ & 30 \\
\hline AIB1 (SRC-3) & Amplified in breast cancer 1 & 31 \\
\hline SREBP1 & Sterol regulatory element binding protein- 1 & 32 \\
\hline JunB & - & 33 \\
\hline $\mathrm{NF}-\kappa \mathrm{B} 2(\mathrm{p} 100)$ & Nuclear factor of $\kappa$ light polypeptide gene enhancer in B cells 2 & 34 \\
\hline Aurora A & Aurora kinase B & 35 \\
\hline Aurora B & Aurora kinase A & 36 \\
\hline CCDC6 & Coiled-coil domain containing 6 & 37 \\
\hline MED13L & Mediator complex subunit 13-like & 38 \\
\hline MED13 & Mediator complex subunit 13 & 38 \\
\hline NF1 & Neurofibromatosis type 1 & 39 \\
\hline KLF2 & Krüppel-like factor 2 & 40 \\
\hline KLF5 & Krüppel-like factor 5 & 41 \\
\hline $\mathrm{C} / \mathrm{EBP} \alpha$ & CCAAT/enhancer binding protein $\alpha$ & 42 \\
\hline $\mathrm{C} / \mathrm{EBP \delta}$ & CCAAT/enhancer binding protein $\delta$ & 43 \\
\hline Nrf1 & Nuclear factor E2-related factor 1 & 44 \\
\hline G-CSFR & Granulocyte colony stimulating factor receptor & 45 \\
\hline CREB3L1 (OASIS) & cAMP responsive element binding protein 3 -like 1 & 46 \\
\hline CREB3L2 (BBF2H7) & cAMP responsive element binding protein 3 -like 2 & 46 \\
\hline TopoII $\alpha$ & Topoisomerase II $\alpha$ & 47 \\
\hline TGIF1 & TGF $\beta$-induced factor 1 & 48 \\
\hline Eya1 & Eyes absent 1 & 49 \\
\hline GATA3 & GATA binding protein 3 & 50 \\
\hline DAB2IP & Disabled homolog 2 interacting protein & 51 \\
\hline PGC-1 $\alpha$ & Peroxisome proliferator-activated receptor- $\gamma$ coactivator $1 \alpha$ & 52 \\
\hline YAP & Yes-associated protein & 53 \\
\hline
\end{tabular}

be regulated by Fbxw7, and are now recognized as potential therapeutic targets. In the present review, we focus on the mechanism by which cyclin E and c-Myc are regulated by Fbxw7.

Fbxw7/cyclin E pathway. By binding to its kinase partner Cdk2, cyclin E regulates the cell cycle by promoting the G1-S transition (71). Deregulation of cyclin E causes genomic instability and is thought to directly contribute to cell transformation and tumorigenesis (72). Cyclin E, containing two CPDs that are phosphorylated by GSK3 and autophosphorylated by Cdk2, respectively, is the most well-studied substrate of Fbxw7 (69). Cyclin E has gained much attention as a key mediator for the tumor-suppressor ability of Fbxw7. Specifically, Fbxw7 tightly regulates the abundance of cyclin E through many molecular mechanisms.

p53 has a complicated and incompletely understood interplay between Fbxw7 and cyclin E. Previous observations revealed that the p53-p21 pathway, which is induced by excess cyclin E, suppresses cyclin E kinase activity and this pathway cooperates with $\mathrm{SCF}^{\mathrm{Fbxw}}$ to suppress cyclin E-induced genome instability $(73,74)$. Moreover, when using a cDNA-microarray system, p53 protein is found to be a transcriptional activator of $F B X W 7 b$ (75). p53 arrests cell cycle progression at G0-G1 by inducing the Fbxw7 $\beta$-mediated downregulation of cyclin $\mathrm{E}$ expression (75). Similarly, another group provided results showing that, p53 regulates the levels of cyclin E protein to impose a G1-S block through the activation of ago in 
Drosophila (76). However, previous findings have also shown that, Fbxw $7 \beta$ is not necessary for the degradation of cyclin $\mathrm{E}$ in mammals as mentioned below. Fbxw7 was eventually proven to act as an upstream of p53 by inducing Aurora A degradation (77). Aurora A phosphorylates p53 at S315/215 and thus reduces p53 levels and transcriptional activity (77) (Fig. 1). However, more studies are needed to clarify these paradoxical and complicated relationships.

Some molecules influence the process whereby Fbxw7 modulates cyclin $\mathrm{E}$ protein degradation, for instance rictor (78), Artemis (79) and SV40 large T (LT) (80) (Fig. 1). Although rictor is usually identified as a binding partner of mTOR, numerous complexes containing rictor have been recognized and shown to be mTOR-independent (81). Fbxw $7 \alpha$ was recently shown to form a complex with rictor. The rictor/Fbxw7 complex functions as an E3 ligase complex, and promotes the degradation of cyclin E in an mTOR-independent manner (78). Artemis, a member of the SNM1 gene family, is a known phosphorylation target of ATM, ATR and DNA-PKcs in response to various types of genotoxic stress (82). In response to UV irradiation, Artemis is phosphorylated at S516 and S645 by the ATR kinase. The phosphorylated Artemis then interacts with $\mathrm{Fbxw} 7 \alpha$ or Fbxw $7 \gamma$ and induces strong ubiquitylation of cyclin E (79). Similarly, the knockdown of rictor by shRNA and inactivation of Artemis by the mutation of S516/645 to alanine can lead to a decreasing ubiquitination of cyclin E $(78,79)$. Contrary to rictor and Artemis, LT negatively regulates the degradation of cyclin E by Fbxw7. LT is a viral oncoprotein producing in cells infected with simian virus 40 (SV40) (83). SV40 LT protein binds to a number of host cell proteins and disrupts their normal functions. Welcker and and Clurman (80) found that LT also has a consensus CPD in its $\mathrm{C}$ terminus that can be phosphorylated at T701, through which LT functions as a competitive inhibitor of Fbxw7 and then deregulates ubiquitination of cyclin E. The Ras/MAPK pathway is also involved in the induction of cyclin E stability by altering the physical interaction between Fbxw 7 and cyclin $\mathrm{E}$, but not by altering cyclin $\mathrm{E}$ phosphorylation on any of its known regulatory sites $(84,85)$ (Fig. 1).

In addition to interacting with $\mathrm{Fbxw} 7$, some factors may target cyclin E and disturb the interaction between Fbxw7 and cyclin E. For example, the protein phosphatase PP2A-B55 $\beta$ targets the $\mathrm{N}$ - and $\mathrm{C}$-terminal phosphodegrons of cyclin $\mathrm{E} 1$ for dephosphorylation, thereby protecting it from degradation mediated by the $\mathrm{SCF}^{\mathrm{Fbxw} 7}$ ubiquitin ligase (86) (Fig. 1). These data suggest the interaction between Fbxw7 and cyclin E is tightly regulated by different regulators. However, as yet unknown regulators remain to be identified in the future.

It has been demonstrated that ubiquitin-mediated degradation of cyclin $\mathrm{E}$ in mammals can be divided into two ways: one requires only Fbxw $7 \alpha$ and the other requires Fbxw $7 \alpha$ and Fbxw7 $\gamma$, although not Fbxw7 $\beta(56,87,88)$ (Fig. 2). When the expression of cyclin $\mathrm{E}$ is low, presumably normal, the inactivation of cyclin E requires Fbxw $7 \alpha$ and Fbxw $7 \gamma$ in a two-step manner. Firstly, cyclin E, which is phosphorylated at $\mathrm{S} 384$ by $\mathrm{Cdk} 2$, interacts with prolyl cis-trans isomerase Pin1 in conjunction with $\mathrm{SCF}^{\mathrm{Fbxw7 \alpha}}$, carries out a noncanonical isomerization of a proline-proline bond in the cyclin E phosphodegron (P382) (56). Then, being mediated by nucleolar protein nucleophosmin (NPM), the complex binds to $\mathrm{SCF}^{\mathrm{Fbxw} 7 \gamma}$ and translocates from the nucleoplasm into the nucleolus where cyclin $\mathrm{E}$ is multiubiquitylated, but does not execute proteasomal degradation (87). Notably, Cdk2 kinase was recently demonstrated to interact with $\mathrm{Fbxw} 7 \gamma$, result in Fbxw7 $\gamma$ degradation (89). This system serves a novel mechanism for rapid inactivation of cyclin $\mathrm{E}$, through separation of cyclin E from its targets.

Some studies have focused on the upstream of the Fbxw7/cyclin E pathway. Their findings have identified many factors that increase or decrease Fbxw7 expression, thus regulating the Fbxw7/cyclin E pathway (Fig. 1). The PI3K/Akt pathway, which was previously thought to be pivotal for the regulation of the GSK phosphorylation, was recently reported to mediate the phosphorylation of Fbxw $7 \alpha$ at S227 (90). This modification stabilizes Fbxw7 and promotes ubiquitylation of the two substrates, cyclin E and c-Myc (90). In addition, Sim et al reported a novel mechanism whereby TRIP-Br proteins links to $\mathrm{E} 2 \mathrm{~F}$ to act as upstream regulators of the Fbxw7/cyclin $\mathrm{E}$ pathway in the maintenance of genomic stability (91). This mechanism reveals a function distinct from the conventional function of E2F, which increases cyclin E expression at the transcriptional level. TRIP-Br proteins interact with PHD zinc finger and/or bromodomain proteins such as KRIP-1 and p300/CBP, upregulate the $F B X W 7$ gene product via the activation of E2F transcriptional activity, and subsequently lead to downregulation of the cyclin E protein (91). Polo-like kinase 2 (PIK2) is also found to directly phosphorylate Fbxw7 at S25, S176 and S349. However, these phosphorylations reduce the stability of Fbxw7, thus stabilizing cyclin E, and contributing to the duplication of centrioles and aneuploidy (92). TAL1, a class II basic helix-loop-helix (bHLH) transcription factor, promotes the malignant phenotype in T-ALL through the repression of Fbxw7 in a miR223-dependent manner. This effect leads to a marked increase of the expression of cyclin $\mathrm{E}$ and c-Myc (93).

The most distinctive function of cyclin $\mathrm{E}$ is to bind to and activate Cdk2. Activation of the cyclin E/Cdk2 complex subsequently leads to the phosphorylation of its substrates, such as retinoblastoma (81), cdc6, NPM, p21 and p27 (72). Of note, cyclin $\mathrm{E} / \mathrm{Cdk} 2$ was reported to directly phosphorylate Cdh1, thus inactivating APC ${ }^{\mathrm{Cdh} 1}$, an E3 ligase important for genomic stability (94). Furthermore, Lau et al showed that the Fbxw7/cyclin E pathway regulates the activation of APC ${ }^{\mathrm{Cdh} 1}$ through direct phosphorylation of Cdh1 (95). This subsequently leads to the inactivation of APC ${ }^{\mathrm{Cdh} 1} \mathrm{E} 3$ ligase and upregulation of APC ${ }^{\mathrm{Cdh} 1}$-specific substrates, which are well-characterized oncoproteins (Fig. 1). These results suggested that Fbxw7 regulates cell cycle through, not only cyclin $\mathrm{E}$ itself, but also the downstream substrates of cyclin E/Cdk2 complex.

Taken together, these findings suggest that Fbxw7/cyclin E is regulated by multiple regulators, which partly explains why there are no $F B X W 7$ gene mutations in some tumors. Moreover, these findings provide insight into the tumor-suppressive function of Fbxw7.

Fbxw7/c-Myc pathway. The c-Myc protein, a basic helix-loophelix zipper (bHLH/Zip)-type transcription factor, generally combines with its cofactor MAX and activates their target genes transcription by binding E-box motifs (CACGTG), and thus playing a predominant role in cell proliferation and tumor- 


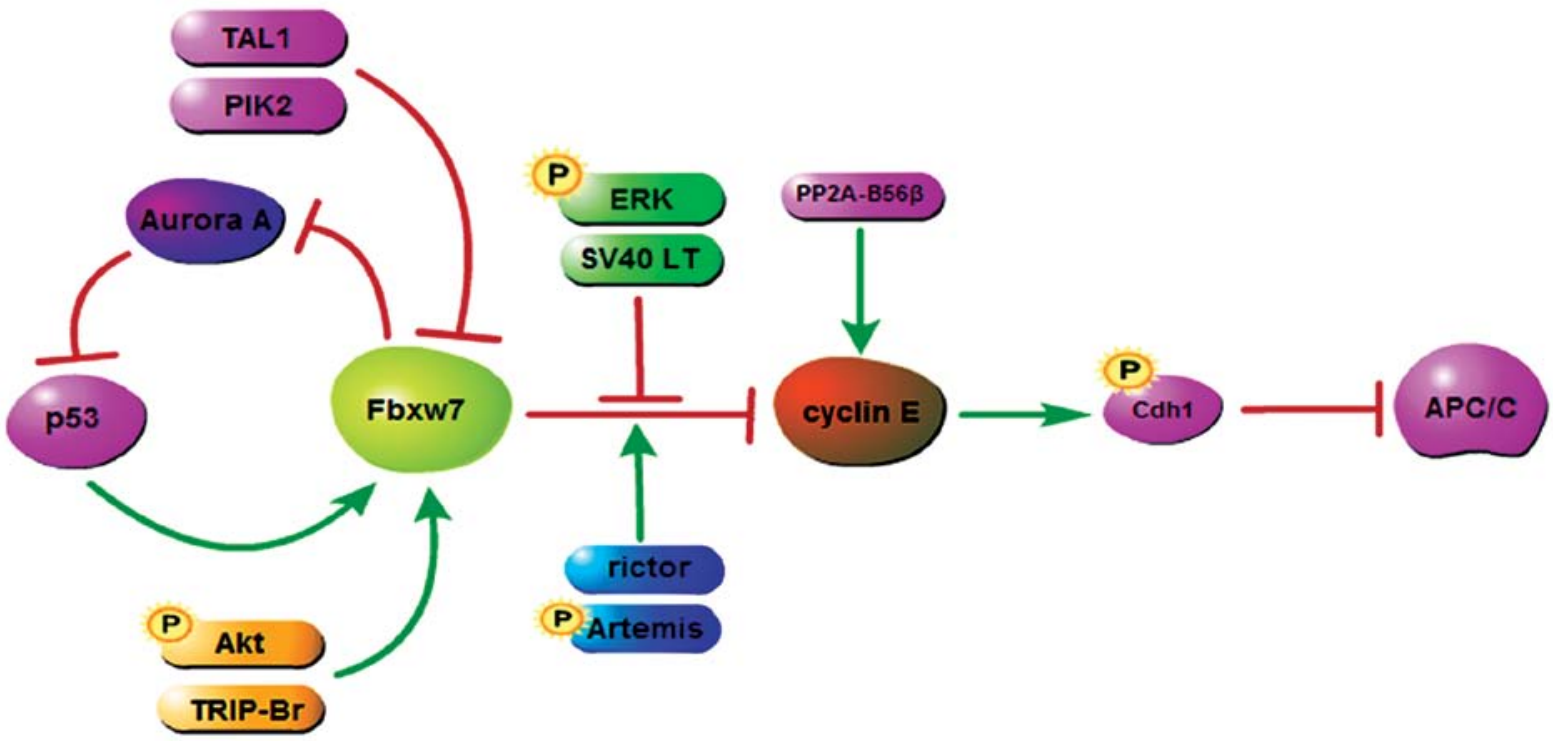

Figure 1. Regulation mechanisms of Fbxw7/cyclin E signaling pathway. Fbxw7/Aurora A/p53 feedback pathway regulates Fbxw7 expression. Other molecular factors such as Akt, TRIP-Br, miR223, PIK2, ERK, SV40 LT, rictor, Artemis, and PP2A-B55 $\beta$ have also been demonstrated to regulate Fbxw7/cyclin E signaling pathway through different mechanisms. Regarding to the downstream of this pathway, APC ${ }^{\text {Cahl }}$ is reported to be an important substrate of the Fbxw7/cyclin E signaling pathway.

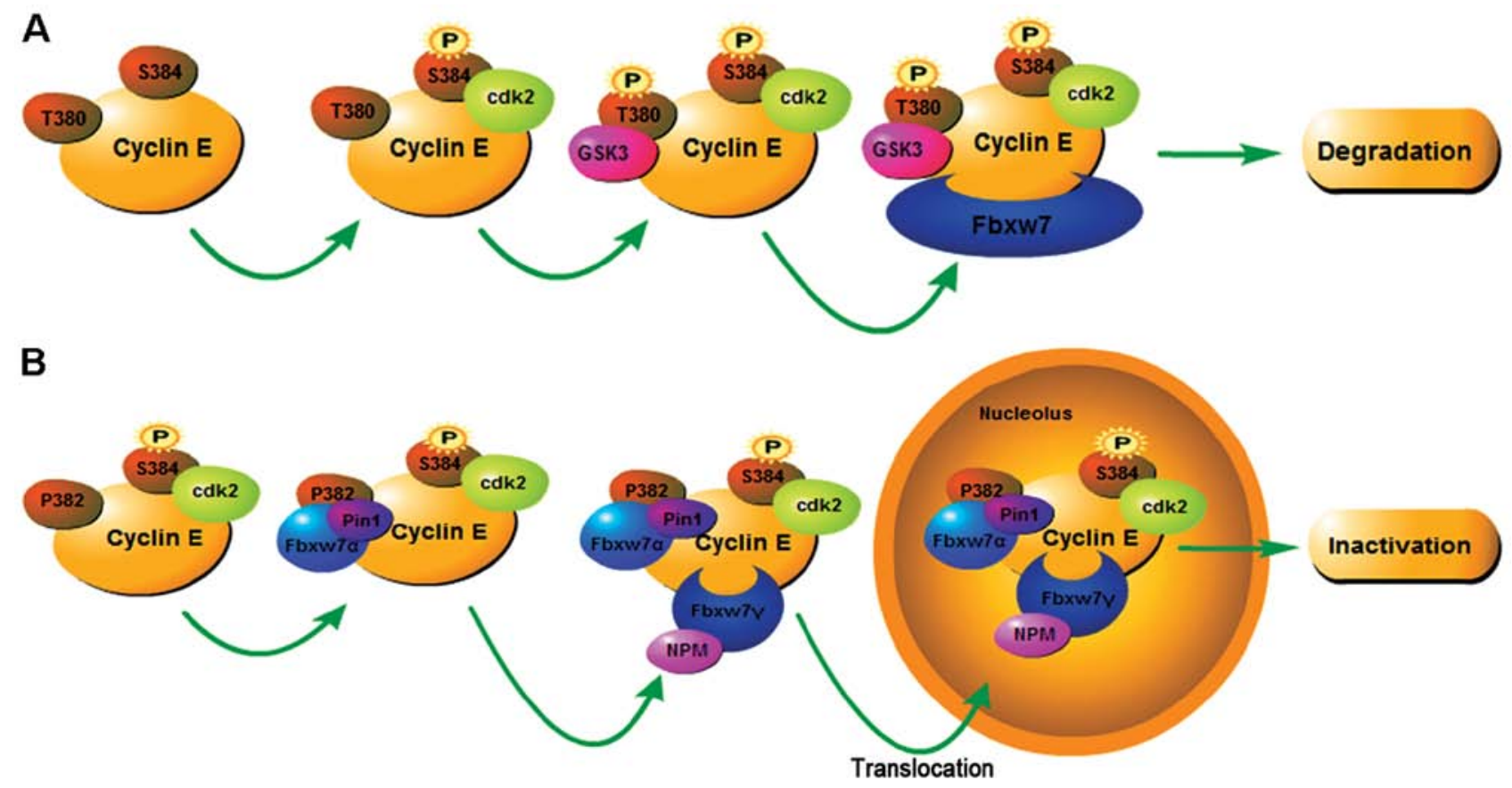

Figure 2. Ubiquitin-dependent proteolysis of cyclin E by Fbxw7 in two situations. (A) When the expression of cyclin E is at a high level, cyclin E is phosphorylated by Cdk2 on S384, and by GSK3 on T380. This hyperphosphorylation on T380 and S384 promotes the contact between Fbxw7 $\alpha$ and cyclin E, leading to the ubiquitin-mediated proteolytic degradation of cyclin E. (B) When the expression of cyclin E is at a low level, cyclin E is phosphorylated by Cdk2 on S384. The phosphorylation of cyclin E leads to contact with Pin1 and Fbxw $7 \alpha$ on P382. Then, being mediated by NPM, the complex binds to Fbxw7 $\gamma$ and translocates into the nucleolus for inactivation.

igenesis (96). Accumulated evidence has indicated that c-Myc protein turnover is tightly regulated at the post-translational level through ubiquitin-proteasome pathway controlled by the $\mathrm{SCF}^{\mathrm{Fbxw}}$ complex $(97,98)$. The oncoprotein c-Myc has only one CPD, containing the sequence PTPPLSP (residues 57-63 in human c-Myc), within which T58 and S62 are the phosphorylation sites (98). However, these two phosphorylation sites exert opposite functions on c-Myc degradation, as the phosphorylation of $\mathrm{S} 62$ results in c-Myc stabilization, whereas the T58 phosphorylation by GSK3 $\beta$ contributes to the interaction between Fbxw7 and c-Myc $(98,99)$. The phosphorylation of T58 depends on the prime phosphorylation of Ser-62. This phosphorylation-dependent proteolysis controlled by $\mathrm{SCF}^{\mathrm{Fbxw}} 7$ is involved with complicated feedback mechanisms.

The activation of Ras-dependent phosphorylation pathways is considered to be important for c-Myc stability mainly 


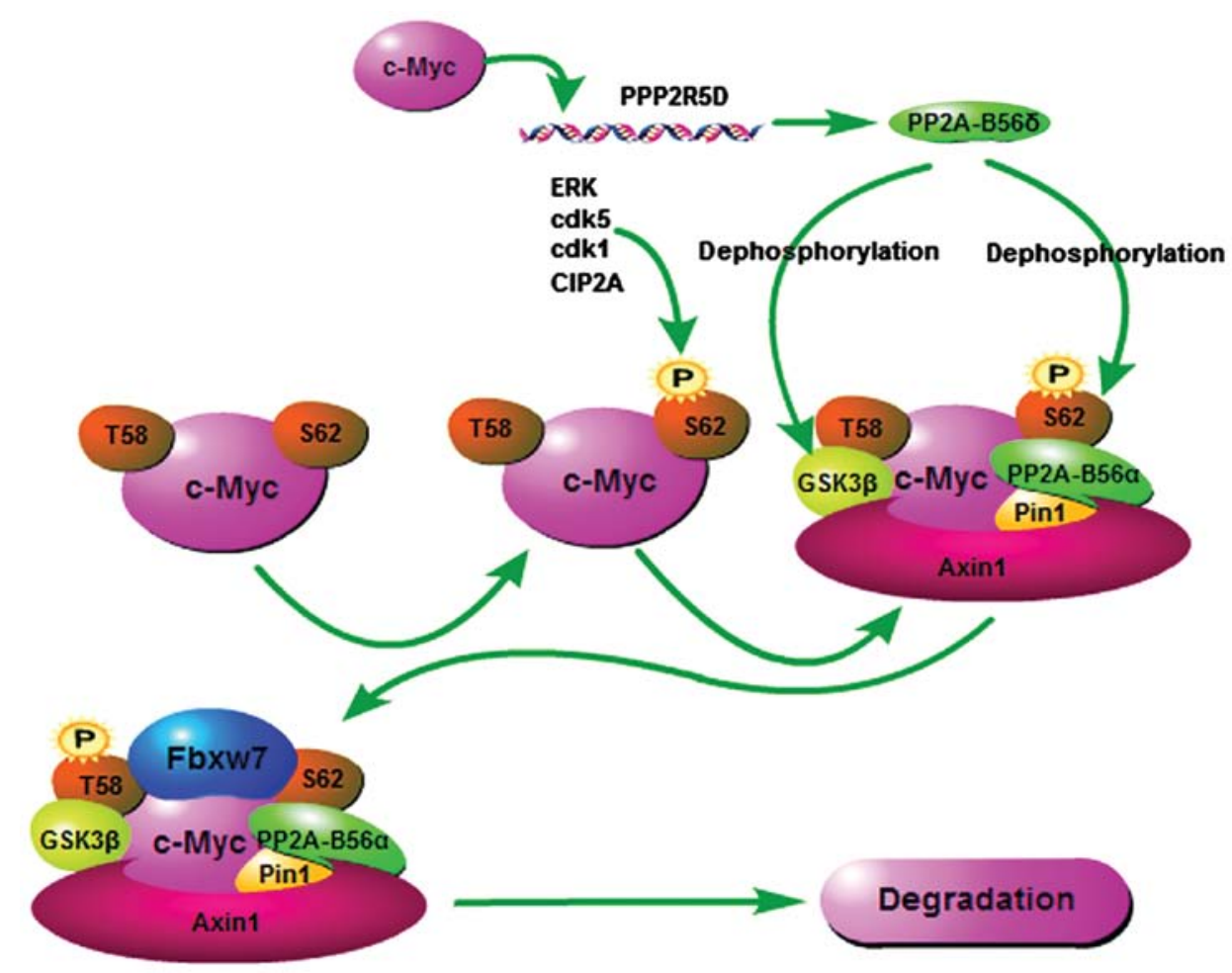

Figure 3. Sequential steps in c-Myc proteolytic degradation by Fbxw7. Multiple factors such as ERK, Cdk5, Cdk1, and CIP2A phosphorylate c-Myc on S62. The initial phosphorylation of S62 allows the connection between Axin1 and c-Myc, forming Axin-Pin1-GSK3 $\beta$-PP2A/B56 $\alpha$ complex to promote c-Myc proteolytic degradation. Moreover, c-Myc can transcriptionally activate the PPP2R5D gene that encodes B568. PP2A-B568 can dephosphorylate S62 within c-Myc and S9 within GSK3 $\beta$, and ultimately facilitate the proteasomal degradation of c-Myc.

through two effective pathways: the Raf/MEK/ERK pathway stabilizes c-Myc by enhancing S62 phosphorylation, and the PI3K/Akt pathway which disrupts the interaction between Fbxw7 and c-Myc by phosphorylating GSK3 $\beta$ at S9, which in turn decreases the phosphorylation of T58 within c-Myc (99). Thus in quiescent cells, where the growth stimulus disappears, Ras activity declines, and the activity of the PI3K/Akt pathway is also downregulated, resulting in the enhancement of T58 phosphorylation and the degradation of c-Myc. It has been shown that the dephosphorylation of S62 is also crucial for the ubiquitin-mediated degradation of c-Myc. T58 phosphorylation is found to facilitate the interaction between c-Myc and Pin1 which catalyzes the isomerization of proline residues in c-Myc to promote S62 dephosphorylation by protein phosphatase 2A (PP2A) (100). Further study showed that Axin1, a multi-domain scaffold protein, regulates this process by facilitating the association of GSK $3 \beta$, B $56 \alpha$ (one of the regulatory subunits of $\mathrm{PP} 2 \mathrm{~A}$ ), and Pin1 with c-Myc, forming an Axin-Pin1-GSK3 $\beta$-PP2A/B56 $\alpha$ complex to promote the ubiquitin-mediated degradation of c-Myc (101). c-Myc has been reported to bind to and transcriptionally activate the PPP2R5D gene that encodes B568 (another regulatory subunit of PP2A) (102). PP2A-B568, not only S dephosphorylates S62 within c-Myc in the same manner as PP2A-B56 $\alpha$, but also reverses the GSK3 $\beta$ inhibitory phosphorylation at $S 9$ by PI3K/Akt (102). These studies provide a mechanism that links c-Myc protein degradation controlled by Fbxw7 to a complicated feedback pathway. In addition, Cdk5, Cdk1 and CIP2A increase $\mathrm{S} 62$ of c-Myc phosphorylation in a direct or indirect manner, resulting in c-Myc stabilization (103-105) (Fig. 3).
Similar to cyclin E, the Fbxw7/c-Myc pathway appears to be linked to many signal molecules. Previous findings have shown that rictor binds to Fbxw7 and facilitates ubiquitination of c-Myc (78). In addition to rictor, other interaction partners such as stomatin-like protein 1 (SLP-1), NPM, and Bloom (BLM) forms complexes with Fbxw7; in particular, Fbxw7 $\gamma$, which is specific for the ubiquitination of c-Myc (89,106-108). By performing a two-hybrid screen, Zhang et al identified that SLP-1, as a novel interaction partner, can bind to the $\mathrm{N}$-terminus of Fbxw $7 \gamma$ and stabilize Fbxw $7 \gamma$, leading to an even greater reduction in c-Myc abundance (89). NPM is required by $\mathrm{Fbxw} 7 \gamma$ for the proper folding, nucleolar localization and stabilization. Mutation of NPM induces delocalization and destabilization of Fbxw7 $\gamma$ and stabilization of c-Myc (106). Recently, BLM, which is a helicase mutated in Bloom syndrome and is conclusively regarded as a sensor of DNA lesion, was reported to have contact with c-Myc and Fbxw7, leading to the degradation of c-Myc and subsequent delay of colorectal tumorigenesis $(108,109)$.

By contrast, many factors serve as binding partners of c-Myc, and block the degradation of c-Myc in a Fbxw7-dependent manner. For example, NF- $\kappa \mathrm{B}$ essential modulator (NEMO) induces the upregulation of c-Myc protein through direct interaction with c-Myc protein and inhibits ubiquitination activity of Fbxw7 without interfering with the interaction of Fbxw7 with T58-phoshorylated c-Myc (110).

Although some studies focus on the interaction mechanism between Fbxw7 and c-Myc, other studies provide mechanistic insights for the regulation of the Fbxw7/c-Myc pathway through a reduction of Fbxw7 expression. For example, NF- $\mathrm{BB} 1$ (p50), 
a ubiquitously expressed subunit of $\mathrm{NF}-\kappa \mathrm{B}$, is thought to suppress $F B X W 7$ gene transcription and upregulate c-Myc protein expression (111). Huang et al revealed that Fbxw7 was profoundly upregulated in p50-deficient cells in comparison to that in p50 intact cells, whereas knockdown of Fbxw7 in $\mathrm{p} 50^{-/}$cells restored arsenite-induced c-Myc protein accumulation (111). COP9 signalosome (CSN) has been found to facilitate the autoubiquitination/degradation of Fbxw7, thereby stabilizing c-Myc (112). Similar to protein factors, some miRNAs participate in the regulation of c-Myc by interfering with the expression of Fbxw7. For example, miR-92 mediates the proteolytic degradation of c-Myc by direct repression of Fbxw7 in a E $\mu$-myc Burkitt's lymphoma model (113). Thus, miR-92 overexpression leads to increase of aberrant c-Myc.

Taken together, the abovementioned studies showed that the Fbxw7/c-Myc pathway is regulated by accurate mechanisms. These mechanisms ensure the cell cycle progression in normal cells and regulate cell proliferation and tumorigenesis in malignant tumors. Moreover, these regulation mechanisms (regulation of the Fbxw7/cylin E and Fbxw7/c-Myc pathways) may also exist in other Fbxw7-specific substrates. Furthermore, the fact that some regulators are involved in the Fbxw7/cyclin E and Fbxw7/c-Myc pathways suggests that the two pathways are important for tumor cell proliferation, and the abnormality of these pathways may be partially regulated by the same mechanisms.

\section{Role of Fbxw7 in hepatocellular carcinoma}

As a tumor suppressor, mRNA and protein expression levels of Fbxw7 have been shown to be downregulated in various types of human cancer. Fbxw7 has been found to be inactivated by mutation in several malignancies with an overall mutation frequency of $\sim 6 \%$ (18). However, no studies have yet reported Fbxw7 mutations in HCC, one of the leading causes of cancerrelated mortality worldwide. Notably, Fbxw7 expression is reported to be important in the regulation of lipogenesis and cell proliferation and differentiation in the liver (114). Using liver-specific Fbxw7 null mice, Onoyama et al found that the hepatic ablation of Fbxw7 resulted in hepatomegaly and steatohepatitis, and long-term Fbxw7 deficiency resulted in marked proliferation of the biliary system and development of hamartomas (114). Moreover, double heterozygous p53 $3^{-/}$Fbxw $7^{-/-}$mice have been proven to develop hepatocarcinomas (35). These results suggest that Fbxw7 is critical for the liver development and tumorigenesis.

Previous studies from different groups have identified the role of Fbxw7 as a tumor suppressor in $\mathrm{HCC}$. Chen et al were the first group to investigate $\mathrm{Fbxw} 7$ in $\mathrm{HCC}$ (47). Their findings revealed that $\mathrm{Fbxw} 7$ promoted ubiquitin-dependent degradation of TopoII $\alpha$ in a HADC-dependent manner (47). Liu et al found that Fbxw7 was involved in the ubiquitin-dependent degradation of AIB1 in Hbx-related HCC (31). Notably, Tu et al were the first group to report that the Fbxw7 mRNA and protein expression in HCC tissues was significantly lower than that in normal tumor-adjacent tissues (115). Subsequently, they also identified that c-Myc, cyclin E, and YAP proteins abundance in $\mathrm{HCC}$ was regulated by Fbxw7 $(53,116)$. Consistent with Tu et al, Imura et al reported a lower Fbxw7 expression in HCC tissues compared with non-tumor liver tissues (117). Coincidentally,

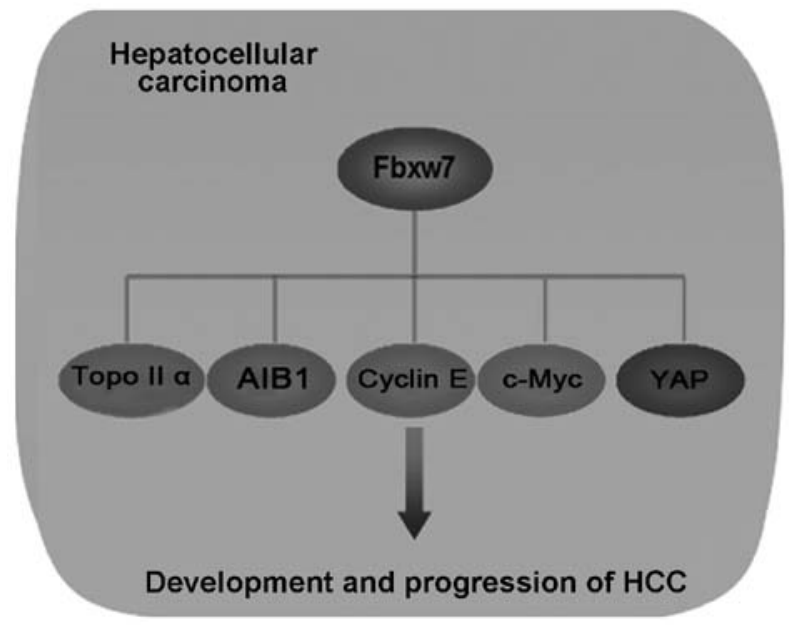

Figure 4. Role of Fbxw7 in HCC. Several proteins such as TopoII $\alpha$, AIB1, cyclin E, c-Myc, and YAP are found to be regulated by Fbxw7 in HCC, demonstrating the critical role Fbxw7 plays as a human tumor suppressor.

all these substrates of Fbxw7 in HCC are closely associated with promoting cancer cell proliferation and tumorigenesis $(53,71,96,118,119)$. Given that c-Myc, YAP and AIB1 have transcriptional activity and promote the transcription of many oncogenes with different functions, Fbxw7 may be associated with controlling cell growth and regulating other malignant behavior, such as invasion and metastasis $(96,120,121)$ (Fig. 4). Taken together, these results show that Fbxw7 plays a critical role in HCC. The inactivation of Fbxw7 in $\mathrm{HCC}$ is involved in tumorigenesis. However, in-depth investigation is required to determine how Fbxw7 is inactivated in HCC and whether other signal pathways, through which Fbxw7 plays as a tumor suppressor in HCC, exist.

\section{Conclusions}

Most cell proteins involved in cell cycle progression, proliferation and apoptosis are regulated by the UPS, which consist of three classes of enzymes (E1, E2 and E3). The SCFF ${ }^{\text {bxw7 }}$ complex is one of the most well-known E3 ligases. Fbxw7, as the substrates-recognition component of the $\mathrm{SCF}^{\mathrm{Fbxw} 7}$ complex, regulates cell proliferation, genetic stability, and tumorigenesis in humans by coordinating the ubiquitin-dependent proteolysis of several key oncoproteins. Several studies (refs?) have identified a growing list of specific substrates of Fbxw7, such as YAP and Eya1. However, cyclin E and c-Myc are the best characterized oncoproteins among the substrates of Fbxw7. Multiple factors tightly regulate the Fbxw7/cyclin E and Fbxw7/c-Myc pathways in different mechanisms. These regulation mechanisms may also exist in other Fbxw7-specific substrates. These mechanisms therefore may be useful in understanding the functions of Fbxw7-related signaling pathways in the regulation of cell proliferation and tumorigenesis in cancer. Furthermore, this understanding reveals Fbxw7-related signaling pathways have potential in developing new targets in cancer therapy. In addition, since many studies have reported that Fbxw7 functions as a tumor suppressor and plays a critical role in regulating several key oncoproteins in HCC, Fbxw7 is a potential therapeutic target in this cancer. However, future 
studies should be conducted to invesigate the mechanism of Fbxw7 and how it may serve as a tumor suppressor in HCC.

\section{Acknowledgements}

This study was supported by grants from the National Natural Science Foundation of China (grant nos. 81301768 and 81372565). The authors would like to thank Professor Qingguang Liu and Dr Kangsheng Tu (Xi'an Jiaotong University, Xi'an, China) for their technical assistance.

\section{References}

1. Ferlay J, Shin HR, Bray F, Forman D, Mathers C and Parkin DM: Estimates of worldwide burden of cancer in 2008: GLOBOCAN 2008. Int J Cancer 127: 2893-2917, 2010.

2. Allemani C, Weir HK, Carreira H, Harewood R, Spika D, Wang XS, Bannon F, Ahn JV, Johnson CJ, Bonaventure A, et al; CONCORD Working Group: Global surveillance of cancer survival 1995-2009: Analysis of individual data for 25,676,887 patients from 279 population-based registries in 67 countries (CONCORD-2). Lancet 385: 977-1010, 2015.

3. Adams J: Development of the proteasome inhibitor PS-341. Oncologist 7: 9-16, 2002

4. Tu Y, Chen C, Pan J, Xu J, Zhou ZG and Wang CY: The Ubiquitin Proteasome Pathway (UPP) in the regulation of cell cycle control and DNA damage repair and its implication in tumorigenesis. In J Clin Exp Pathol 5: 726-738, 2012.

5. Bedford L, Lowe J, Dick LR, Mayer RJ and Brownell JE: Ubiquitin-like protein conjugation and the ubiquitin-proteasome system as drug targets. Nat Rev Drug Discov 10: 29-46, 2011.

6. Voutsadakis IA: The ubiquitin-proteasome system and signal transduction pathways regulating Epithelial Mesenchymal transition of cancer. J Biomed Sci 19: 67, 2012.

7. Devoy A, Soane T, Welchman R and Mayer RJ: The ubiquitinproteasome system and cancer. Essays Biochem 41: 187-203, 2005 .

8. Komander D: The emerging complexity of protein ubiquitination. Biochem Soc Trans 37: 937-953, 2009.

9. Pickart CM: Mechanisms underlying ubiquitination. Annu Rev Biochem 70: 503-533, 2001.

10. Zheng N, Schulman BA, Song L, Miller JJ, Jeffrey PD, Wang P, Chu C, Koepp DM, Elledge SJ, Pagano M, et al: Structure of the Cul1-Rbx1-Skp1-F boxSkp2 SCF ubiquitin ligase complex. Nature 416: 703-709, 2002.

11. Schulman BA, Carrano AC, Jeffrey PD, Bowen Z, Kinnucan ER Finnin MS, Elledge SJ, Harper JW, Pagano M and Pavletich NP: Insights into $\mathrm{SCF}$ ubiquitin ligases from the structure of the Skp1-Skp2 complex. Nature 408: 381-386, 2000.

12. Hartwell LH, Mortimer RK, Culotti J and Culotti M: Genetic control of the cell division cycle in yeast: V. genetic analysis of $c d c$ mutants. Genetics 74: 267-286, 1973.

13. Hubbard EJ, Wu G, Kitajewski J and Greenwald I: sel-10, a negative regulator of lin-12 activity in Caenorhabditis elegans, encodes a member of the CDC4 family of proteins. Genes Dev 11: 3182-3193, 1997.

14. Moberg KH, Bell DW, Wahrer DC, Haber DA and Hariharan IK Archipelago regulates Cyclin E levels in Drosophila and is mutated in human cancer cell lines. Nature 413: 311-316, 2001.

15. Welcker M and Clurman BE: FBW7 ubiquitin ligase: A tumour suppressor at the crossroads of cell division, growth and differentiation. Nat Rev Cancer 8: 83-93, 2008.

16. Rajagopalan H, Jallepalli PV, Rago C, Velculescu VE, Kinzler KW, Vogelstein B and Lengauer C: Inactivation of $h C D C 4$ can cause chromosomal instability. Nature 428: 77-81, 2004.

17. Spruck CH, Strohmaier H, Sangfelt O, Müller HM, Hubalek M, Müller-Holzner E, Marth C, Widschwendter M and Reed SI: $h C D C 4$ gene mutations in endometrial cancer. Cancer Res 62: 4535-4539, 2002 .

18. Akhoondi S, Sun D, von der Lehr N, Apostolidou S, Klotz K, Maljukova A, Cepeda D, Fiegl H, Dafou D, Marth C, et al: $F B X W 7 / h C D C 4$ is a general tumor suppressor in human cancer. Cancer Res 67: 9006-9012, 2007.

19. Davis H, Lewis A, Behrens A and Tomlinson I: Investigation of the atypical $F B X W 7$ mutation spectrum in human tumours by conditional expression of a heterozygous propellor tip missense allele in the mouse intestines. Gut 63: 792-799, 2014.
20. Koepp DM, Schaefer LK, Ye X, Keyomarsi K, Chu C, Harper JW and Elledge SJ: Phosphorylation-dependent ubiquitination of cyclin $\mathrm{E}$ by the $\mathrm{SCF}^{\mathrm{Fbw} 7}$ ubiquitin ligase. Science 294: 173-177, 2001.

21. Yada M, Hatakeyama S, Kamura T, Nishiyama M, Tsunematsu R, Imaki H, Ishida N, Okumura F, Nakayama K and Nakayama KI: Phosphorylation-dependent degradation of c-Myc is mediated by the F-box protein Fbw7. EMBO J 23: 2116-2125, 2004.

22. Wei W, Jin J, Schlisio S, Harper JW and Kaelin WG Jr: The v-Jun point mutation allows c-Jun to escape GSK3-dependent recognition and destruction by the Fbw7 ubiquitin ligase. Cancer Cell 8: 25-33, 2005.

23. O'Neil J, Grim J, Strack P, Rao S, Tibbitts D, Winter C, Hardwick J, Welcker M, Meijerink JP, Pieters R, et al: FBW7 mutations in leukemic cells mediate NOTCH pathway activation and resistance to gamma-secretase inhibitors. J Exp Med 204: 1813-1824, 2007

24. Inuzuka H, Shaik S, Onoyama I, Gao D, Tseng A, Maser RS, Zhai B, Wan L, Gutierrez A, Lau AW, et al: $\mathrm{SCF}^{\mathrm{FBW}}$ regulates cellular apoptosis by targeting MCL1 for ubiquitylation and destruction. Nature 471: 104-109, 2011.

25. Mao JH, Kim IJ, Wu D, Climent J, Kang HC, DelRosario R and Balmain A: FBXW7 targets mTOR for degradation and cooperates with PTEN in tumor suppression. Science 321: 1499-1502, 2008.

26. Li J, Pauley AM, Myers RL, Shuang R, Brashler JR, Yan R, Buhl AE, Ruble C and Gurney ME: SEL-10 interacts with presenilin 1, facilitates its ubiquitination, and alters A-beta peptide production. J Neurochem 82: 1540-1548, 2002.

27. Brockmann M, Poon E, Berry T, Carstensen A, Deubzer HE, Rycak L, Jamin Y, Thway K, Robinson SP, Roels F, et al: Small molecule inhibitors of aurora-a induce proteasomal degradation of N-myc in childhood neuroblastoma. Cancer Cell 24: 75-89, 2013.

28. Galli F, Rossi M, D'Alessandra Y, De Simone M, Lopardo T, Haupt Y, Alsheich-Bartok O, Anzi S, Shaulian E, Calabrò V, et al: MDM2 and Fbw7 cooperate to induce p63 protein degradation following DNA damage and cell differentiation. J Cell Sci 123: 2423-2433, 2010.

29. Kitagawa K, Hiramatsu Y, Uchida C, Isobe T, Hattori T, Oda T, Shibata K, Nakamura S, Kikuchi A and Kitagawa M: Fbw7 promotes ubiquitin-dependent degradation of c-Myb: Involvement of GSK3-mediated phosphorylation of Thr-572 in mouse c-Myb. Oncogene 28: 2393-2405, 2009.

30. Cassavaugh JM, Hale SA, Wellman TL, Howe AK, Wong C and Lounsbury KM: Negative regulation of HIF- $1 \alpha$ by an FBW7-mediated degradation pathway during hypoxia. J Cell Biochem 112: 3882-3890, 2011.

31. Liu Y, Tong Z, Li T, Chen Q, Zhuo L, Li W, Wu RC and Yu C: Hepatitis B virus $\mathrm{X}$ protein stabilizes amplified in breast cancer 1 protein and cooperates with it to promote human hepatocellular carcinoma cell invasiveness. Hepatology 56: 1015-1024, 2012.

32. Tu K, Zheng X, Yin G, Zan X, Yao Y and Liu Q: Evaluation of Fbxw7 expression and its correlation with expression of SREBP-1 in a mouse model of NAFLD. Mol Med Rep 6: 525-530, 2012.

33. Pérez-Benavente B, García JL, Rodríguez MS, Pineda-Lucena A, Piechaczyk M, Font de Mora J and Farràs R: GSK3-SCF ${ }^{\mathrm{FBXW}}$ targets JunB for degradation in G2 to preserve chromatid cohesion before anaphase. Oncogene 32: 2189-2199, 2013.

34. Arabi A, Ullah K, Branca RM, Johansson J, Bandarra D, Haneklaus M, Fu J, Ariës I, Nilsson P, Den Boer ML, et al: Proteomic screen reveals Fbw7 as a modulator of the NF- $\mathrm{kB}$ pathway. Nat Commun 3: 976, 2012.

35. Mao JH, Perez-Losada J, Wu D, Delrosario R, Tsunematsu R, Nakayama KI, Brown K, Bryson S and Balmain A: Fbxw7/Cdc4 is a p53-dependent, haploinsufficient tumour suppressor gene. Nature 432: 775-779, 2004.

36. Teng CL, Hsieh YC, Phan L, Shin J, Gully C, Velazquez-Torres G, Skerl S, Yeung SC, Hsu SL and Lee MH: FBXW7 is involved in Aurora B degradation. Cell Cycle 11: 4059-4068, 2012.

37. Zhao J, Tang J, Men W and Ren K: FBXW7-mediated degradation of CCDC6 is impaired by ATM during DNA damage response in lung cancer cells. FEBS Lett 586: 4257-4263, 2012.

38. Davis MA, Larimore EA, Fissel BM, Swanger J, Taatjes DJ and Clurman BE: The SCF-Fbw7 ubiquitin ligase degrades MED13 and MED13L and regulates CDK8 module association with Mediator. Genes Dev 27: 151-156, 2013.

39. Tan M, Zhao Y, Kim SJ, Liu M, Jia L, Saunders TL, Zhu Y and Sun Y: SAG/RBX2/ROC2 E3 ubiquitin ligase is essential for vascular and neural development by targeting NF1 for degradation. Dev Cell 21: 1062-1076, 2011. 
40. Wang R, Wang Y, Liu N, Ren C, Jiang C, Zhang K, Yu S, Chen Y, Tang H, Deng Q, et al: FBW7 regulates endothelial functions by targeting KLF2 for ubiquitination and degradation. Cell Res 23 : $803-819,2013$

41. Bialkowska AB, Liu Y, Nandan MO and Yang VW: A colon cancer-derived mutant of Krüppel-like factor 5 (KLF5) is resistant to degradation by glycogen synthase kinase $3 \beta$ (GSK3 $\beta$ ) and the E3 ubiquitin ligase F-box and WD repeat domain-containing $7 \alpha$ (FBW7 $\alpha$ ). J Biol Chem 289: 5997-6005, 2014.

42. Bengoechea-Alonso MT and Ericsson J: The ubiquitin ligase Fbxw7 controls adipocyte differentiation by targeting C/EBPalpha for degradation. Proc Natl Acad Sci USA 107: 11817-11822, 2010.

43. Balamurugan K, Sharan S, Klarmann KD, Zhang Y, Coppola V, Summers GH, Roger T, Morrison DK, Keller JR and Sterneck E: FBXW7 $\alpha$ attenuates inflammatory signalling by downregulating C/EBPS and its target gene Tlr4. Nat Commun 4: 1662, 2013

44. Biswas M, Phan D, Watanabe M and Chan JY: The Fbw7 tumor suppressor regulates nuclear factor E2-related factor 1 transcription factor turnover through proteasome-mediated proteolysis. J Biol Chem 286: 39282-39289, 2011.

45. Lochab S, Pal P, Kapoor I, Kanaujiya JK, Sanyal S, Behre G and Trivedi AK: E3 ubiquitin ligase Fbw7 negatively regulates granulocytic differentiation by targeting G-CSFR for degradation. Biochim Biophys Acta 1833: 2639-2652, 2013.

46. Yumimoto K, Matsumoto M, Onoyama I, Imaizumi K and Nakayama KI: F-box and WD repeat domain-containing-7 (Fbxw7) protein targets endoplasmic reticulum-anchored osteogenic and chondrogenic transcriptional factors for degradation. J Biol Chem 288: 28488-28502, 2013.

47. Chen MC, Chen CH, Chuang HC, Kulp SK, Teng CM and Chen CS: Novel mechanism by which histone deacetylase inhibitors facilitate topoisomerase II $\alpha$ degradation in hepatocellular carcinoma cells. Hepatology 53: 148-159, 2011.

48. Bengoechea-Alonso MT and Ericsson J: Tumor suppressor Fbxw7 regulates TGF $\beta$ signaling by targeting TGIF1 for degradation. Oncogene 29: 5322-5328, 2010.

49. Sun Y and Li X: The canonical wnt signal restricts the glycogen synthase kinase 3/fbw7-dependent ubiquitination and degradation of eya1 phosphatase. Mol Cell Biol 34: 2409-2417, 2014.

50. Kitagawa K, Shibata K, Matsumoto A, Matsumoto M, Ohhata T, Nakayama KI, Niida H and Kitagawa M: Fbw7 targets GATA3 through cyclin-dependent kinase 2-dependent proteolysis and contributes to regulation of T-cell development. Mol Cell Biol 34: 2732-2744, 2014

51. Dai X, North BJ and Inuzuka H: Negative regulation of DAB2IP by Akt and $\mathrm{SCF}^{\mathrm{Fbw} 7}$ pathways. Oncotarget 5: 3307-3315, 2014.

52. Trausch-Azar JS, Abed M, Orian A and Schwartz AL: Isoformspecific $\mathrm{SCF}^{\mathrm{Fbw}} 7$ ubiquitination mediates differential regulation of PGC-1 $\alpha$. J Cell Physiol 230: 842-852, 2015.

53. Tu K, Yang W, Li C, Zheng X, Lu Z, Guo C, Yao Y and Q: Fbxw7 is an independent prognostic marker and induces apoptosis and growth arrest by regulating YAP abundance in hepatocellular carcinoma. Mol Cancer 13: 110, 2014.

54. Jin J, Cardozo T, Lovering RC, Elledge SJ, Pagano $M$ and Harper JW: Systematic analysis and nomenclature of mammalian F-box proteins. Genes Dev 18: 2573-2580, 2004

55. Sterian A, Kan T, Berki AT, Mori Y, Olaru A, Schulmann K, Sato F, Wang S, Paun B, Cai K, et al: Mutational and LOH analyses of the chromosome $4 \mathrm{q}$ region in esophageal adenocarcinoma. Oncology 70: 168-172, 2006.

56. van Drogen F, Sangfelt O, Malyukova A, Matskova L, Yeh E, Means AR and Reed SI: Ubiquitylation of cyclin E requires the sequential function of SCF complexes containing distinct hCdc4 isoforms. Mol Cell 23: 37-48, 2006.

57. Matsumoto A, Tateishi Y, Onoyama I, Okita Y, Nakayama K and Nakayama KI: Fbxw7 $\beta$ resides in the endoplasmic reticulum membrane and protects cells from oxidative stress. Cancer Sci 102: 749-755, 2011.

58. Ren H, Zhao L, Li Y, Yue P, Deng X, Owonikoko TK, Chen M, Khuri FR and Sun SY: The PI3 kinase inhibitor NVP-BKM120 induces GSK3/FBXW7-dependent Mcl-1 degradation, contributing to induction of apoptosis and enhancement of TRAIL-induced apoptosis. Cancer Lett 338: 229-238, 2013.

59. Embi N, Rylatt DB and Cohen P: Glycogen synthase kinase-3 from rabbit skeletal muscle. Separation from cyclic-AMPdependent protein kinase and phosphorylase kinase. Eur J Biochem 107: 519-527, 1980.

60. Woodgett JR: Molecular cloning and expression of glycogen synthase kinase-3/factor A. EMBO J 9: 2431-2438, 1990.

61. Wu D and Pan W: GSK3: A multifaceted kinase in Wnt signaling. Trends Biochem Sci 35: 161-168, 2010.
62. Kim L and Kimmel AR: GSK3, a master switch regulating cell-fate specification and tumorigenesis. Curr Opin Genet Dev 10: 508-514, 2000.

63. Buttrick GJ and Wakefield JG: PI3-K and GSK-3: Akt-ing together with microtubules. Cell Cycle 7: 2621-2625, 2008.

64. Welcker M, Singer J, Loeb KR, Grim J, Bloecher A, Gurien-West M, Clurman BE and Roberts JM: Multisite phosphorylation by Cdk2 and GSK 3 controls cyclin E degradation. Mol Cell 12: 381-392, 2003.

65. Hao B, Oehlmann S, Sowa ME, Harper JW and Pavletich NP: Structure of a Fbw7-Skp1-cyclin E complex: Multisitephosphorylated substrate recognition by SCF ubiquitin ligases. Mol Cell 26: 131-143, 2007.

66. Bahram F, von der Lehr N, Cetinkaya C and Larsson LG: c-Myc hot spot mutations in lymphomas result in inefficient ubiquitination and decreased proteasome-mediated turnover. Blood 95: 2104-2110, 2000.

67. Tan Y, Sangfelt O and Spruck C: The Fbxw7/hCdc4 tumor suppressor in human cancer. Cancer Lett 271: 1-12, 2008.

68. Strohmaier H, Spruck CH, Kaiser P, Won KA, Sangfelt O and Reed SI: Human F-box protein hCdc4 targets cyclin E for proteolysis and is mutated in a breast cancer cell line. Nature 413: 316-322, 2001.

69. Ye X, Nalepa G, Welcker M, Kessler BM, Spooner E, Qin J, Elledge SJ, Clurman BE and Harper JW: Recognition of phosphodegron motifs in human cyclin $\mathrm{E}$ by the $\mathrm{SCF}^{\mathrm{Fbw}}$ ubiquitin ligase. J Biol Chem 279: 50110-50119, 2004.

70. Welcker $M$ and Clurman BE: Fbw7/hCDC4 dimerization regulates its substrate interactions. Cell Div 2: 7, 2007.

71. Geng Y, Lee YM, Welcker M, Swanger J, Zagozdzon A, Winer JD, Roberts JM, Kaldis P, Clurman BE and Sicinski P: Kinaseindependent function of cyclin E. Mol Cell 25: 127-139, 2007.

72. Siu KT, Rosner MR and Minella AC: An integrated view of cyclin E function and regulation. Cell Cycle 11: 57-64, 2012.

73. Minella AC, Grim JE, Welcker M and Clurman BE: p53 and $\mathrm{SCF}^{\mathrm{Fbw}} 7$ cooperatively restrain cyclin E-associated genome instability. Oncogene 26: 6948-6953, 2007.

74. Minella AC, Swanger J, Bryant E, Welcker M, Hwang H and Clurman BE: p53 and p21 form an inducible barrier that protects cells against cyclin E-cdk2 deregulation. Curr Biol 12: 1817-1827, 2002.

75. Kimura T, Gotoh M, Nakamura $\mathrm{Y}$ and Arakawa $\mathrm{H}$ : $h C D C 4 b$, a regulator of cyclin $\mathrm{E}$, as a direct transcriptional target of p53. Cancer Sci 94: 431-436, 2003.

76. Mandal S, Freije WA, Guptan P and Banerjee U: Metabolic control of G1-S transition: Cyclin E degradation by p53-induced activation of the ubiquitin-proteasome system. J Cell Biol 188: 473-479, 2010

77. Finkin S, Aylon Y, Anzi S, Oren M and Shaulian E: Fbw7 regulates the activity of endoreduplication mediators and the p53 pathway to prevent drug-induced polyploidy. Oncogene 27: 4411-4421, 2008

78. Guo Z,Zhou Y, Evers BM and Wang Q: Rictor regulates FBXW7dependent c-Myc and cyclin E degradation in colorectal cancer cells. Biochem Biophys Res Commun 418: 426-432, 2012.

79. Wang H, Zhang X, Geng L, Teng L and Legerski RJ: Artemis regulates cell cycle recovery from the $S$ phase checkpoint by promoting degradation of cyclin E. J Biol Chem 284: $18236-18243,2009$.

80. Welcker M and Clurman BE: The SV40 large T antigen contains a decoy phosphodegron that mediates its interactions with Fbw7/hCdc4. J Biol Chem 280: 7654-7658, 2005.

81. Sarbassov DD, Ali SM, Kim DH, Guertin DA, Latek RR, Erdjument-Bromage H, Tempst P and Sabatini DM: Rictor, a novel binding partner of mTOR, defines a rapamycin-insensitive and raptor-independent pathway that regulates the cytoskeleton. Curr Biol 14: 1296-1302, 2004.

82. Poinsignon C, de Chasseval R, Soubeyrand S, Moshous D, Fischer A, Haché RJ and de Villartay JP: Phosphorylation of Artemis following irradiation-induced DNA damage. Eur $\mathbf{J}$ Immunol 34: 3146-3155, 2004.

83. Ahuja D, Sáenz-Robles MT and Pipas JM: SV40 large T antigen targets multiple cellular pathways to elicit cellular transformation. Oncogene 24: 7729-7745, 2005.

84. Minella AC, Welcker M and Clurman BE: Ras activity regulates cyclin E degradation by the Fbw7 pathway. Proc Natl Acad Sci USA 102: 9649-9654, 2005.

85. Hynes NE and Lane HA: ERBB receptors and cancer: The complexity of targeted inhibitors. Nat Rev Cancer 5: 341-354, 2005 . 
86. Tan Y, Sun D, Jiang W, Klotz-Noack K, Vashisht AA Wohlschlegel J, Widschwendter M and Spruck C: PP2A-B55 $\beta$ antagonizes cyclin E1 proteolysis and promotes its dysregulation in cancer. Cancer Res 74: 2006-2014, 2014.

87. Bhaskaran N, van Drogen F, Ng HF, Kumar R, Ekholm-Reed S, Peter M, Sangfelt O and Reed SI: Fbw $7 \alpha$ and Fbw $7 \gamma$ collaborate to shuttle cyclin E1 into the nucleolus for multiubiquitylation. Mol Cell Biol 33: 85-97, 2013.

88. Reed SI: Cooperation between different $\mathrm{Cdc} 4 / \mathrm{Fbw} 7$ isoforms may be associated with 2-step inactivation of SCFCdc4 targets. Cell Cycle 5: 1923-1924, 2006.

89. Zhang W, MacDonald EM and Koepp DM: The stomatin-like protein SLP-1 and Cdk2 interact with the F-Box protein Fbw7- $\gamma$. PLoS One 7: e47736, 2012.

90. Schülein C, Eilers M and Popov N: PI3K-dependent phosphorylation of Fbw7 modulates substrate degradation and activity. FEBS Lett 585: 2151-2157, 2011.

91. Sim KG, Zang Z, Yang CM, Bonventre JV and Hsu SI: TRIP-Br links E2F to novel functions in the regulation of cyclin E expression during cell cycle progression and in the maintenance of genomic stability. Cell Cycle 3: 1296-1304, 2004.

92. Cizmecioglu O, Krause A, Bahtz R, Ehret L, Malek N and Hoffmann I: Plk2 regulates centriole duplication through phosphorylation-mediated degradation of Fbxw7 (human Cdc4). J Cell Sci 125: 981-992, 2012.

93. Mansour MR, Sanda T, Lawton LN, Li X, Kreslavsky T, Novina CD, Brand M, Gutierrez A, Kelliher MA, Jamieson CH, et al: The TAL1 complex targets the $F B X W 7$ tumor suppressor by activating miR-223 in human T cell acute lymphoblastic leukemia. J Exp Med 210: 1545-1557, 2013.

94. Keck JM, Summers MK, Tedesco D, Ekholm-Reed S, Chuang LC, Jackson PK and Reed SI: Cyclin E overexpression impairs progression through mitosis by inhibiting $\mathrm{APC}^{\mathrm{Cdh} 1}$. J Cell Biol 178: 371-385, 2007.

95. Lau AW, Inuzuka H, Fukushima H, Wan L, Liu P, Gao D, Sun Y and Wei W: Regulation of $\mathrm{APC}^{\mathrm{Cdh} 1} \mathrm{E} 3$ ligase activity by the Fbw7/cyclin E signaling axis contributes to the tumor suppressor function of Fbw7. Cell Res 23: 947-961, 2013.

96. Meyer N and Penn LZ: Reflecting on 25 years with MYC. Nat Rev Cancer 8: 976-990, 2008.

97. Onoyama I, Tsunematsu R, Matsumoto A, Kimura T, de Alborán IM, Nakayama K and Nakayama KI: Conditional inactivation of Fbxw7 impairs cell-cycle exit during $\mathrm{T}$ cell differentiation and results in lymphomatogenesis. J Exp Med 204: 2875-2888, 2007.

98. Welcker M, Orian A, Jin J, Grim JE, Harper JW, Eisenman RN and Clurman BE: The Fbw7 tumor suppressor regulates glycogen synthase kinase 3 phosphorylation-dependent c-Myc protein degradation. Proc Natl Acad Sci USA 101: 9085-9090, 2004.

99. Sears R, Nuckolls F, Haura E, Taya Y, Tamai K and Nevins JR: Multiple Ras-dependent phosphorylation pathways regulate Myc protein stability. Genes Dev 14: 2501-2514, 2000.

100. Yeh E, Cunningham M, Arnold H, Chasse D, Monteith T, Ivaldi G, Hahn WC, Stukenberg PT, Shenolikar S, Uchida T, et al: A signalling pathway controlling c-Myc degradation that impacts oncogenic transformation of human cells. Nat Cell Biol 6: 308-318, 2004.

101. Arnold HK, Zhang X, Daniel CJ, Tibbitts D, EscamillaPowers J, Farrell A, Tokarz S, Morgan C and Sears RC: The Axin1 scaffold protein promotes formation of a degradation complex for c-Myc. EMBO J 28: 500-512, 2009.

102. Liu L and Eisenman RN: Regulation of c-Myc protein abundance by a protein phosphatase $2 \mathrm{~A}$-glycogen synthase kinase 3 $\beta$-negative feedback pathway. Genes Cancer 3: 23-36, 2012.

103. Seo HR, Kim J, Bae S, Soh JW and Lee YS: Cdk5-mediated phosphorylation of c-Myc on Ser-62 is essential in transcriptional activation of cyclin B1 by cyclin G1. J Biol Chem 283: 15601-15610, 2008.
104. Sjostrom SK, Finn G, Hahn WC, Rowitch DH and Kenney AM: The Cdk1 complex plays a prime role in regulating $\mathrm{N}$-myc phosphorylation and turnover in neural precursors. Dev Cell 9: 327-338, 2005

105. Junttila MR, Puustinen P, Niemelä M, Ahola R, Arnold H, Böttzauw T, Ala-aho R, Nielsen C, Ivaska J, Taya Y, et al: CIP2A inhibits PP2A in human malignancies. Cell 130: 51-62, 2007.

106. Bonetti P, Davoli T, Sironi C, Amati B, Pelicci PG and Colombo E: Nucleophosmin and its AML-associated mutant regulate c-Myc turnover through Fbw7 gamma. J Cell Biol 182: 19-26, 2008

107. Welcker M, Orian A, Grim JE, Eisenman RN and Clurman BE: A nucleolar isoform of the Fbw7 ubiquitin ligase regulates c-Myc and cell size. Curr Biol 14: 1852-1857, 2004

108. Chandra S, Priyadarshini R, Madhavan V, Tikoo S, Hussain M, Mudgal R, Modi P, Srivastava V and Sengupta S: Enhancement of c-Myc degradation by BLM helicase leads to delayed tumor initiation. J Cell Sci 126: 3782-3795, 2013.

109. Tikoo S and Sengupta S: Time to bloom. Genome Integr 1: 14 , 2010.

110. Kim BY, Yang JS, Kwak SY, Zhang XK and Han YH: NEMO stabilizes c-Myc through direct interaction in the nucleus. FEBS Lett 584: 4524-4530, 2010.

111. Huang H, Ma L, Li J, Yu Y, Zhang D, Wei J, Jin H, Xu D, Gao $J$ and Huang C: NF- $\kappa \mathrm{B} 1$ inhibits c-Myc protein degradation through suppression of FBW7 expression. Oncotarget 5: 493-505, 2014.

112. Chen J, Shin JH, Zhao R, Phan L, Wang H, Xue Y, Post SM, Ho Choi $\mathrm{H}$, Chen JS, Wang E, et al: CSN6 drives carcinogenesis by positively regulating Myc stability. Nat Commun 5: 5384, 2014.

113. Olive V, Sabio E, Bennett MJ, De Jong CS, Biton A, McGann JC, Greaney SK, Sodir NM, Zhou AY, Balakrishnan A, et al: A component of the mir-17-92 polycistronic oncomir promotes oncogene-dependent apoptosis. eLife 2: e00822, 2013.

114. Onoyama I, Suzuki A, Matsumoto A, Tomita K, Katagiri H, Oike Y, Nakayama K and Nakayama KI: Fbxw7 regulates lipid metabolism and cell fate decisions in the mouse liver. J Clin Invest 121: 342-354, 2011.

115. Tu K, Zheng X, Zan X, Han S, Yao Y and Liu Q: Evaluation of Fbxw7 expression and its correlation with the expression of c-Myc, cyclin E and p53 in human hepatocellular carcinoma. Hepatol Res 42: 904-910, 2012.

116. Tu K, Zheng X, Zhou Z, Li C, Zhang J, Gao J, Yao Y and Liu Q: Recombinant human adenovirus-p53 injection induced apoptosis in hepatocellular carcinoma cell lines mediated by p53-Fbxw7 pathway, which controls c-Myc and cyclin E. PLoS One 8: e68574, 2013.

117. Imura S, Tovuu LO, Utsunomiya $\mathrm{T}$, Morine $\mathrm{Y}$, Ikemoto $\mathrm{T}$, Arakawa Y, Kanamoto M, Iwahashi S, Saito Y, Takasu C, et al: The role of Fbxw7 expression in hepatocellular carcinoma and adjacent non-tumor liver tissue. J Gastroenterol Hepatol 29: 1822-1829, 2014.

118. Tien JC and Xu J: Steroid receptor coactivator-3 as a potential molecular target for cancer therapy. Expert Opin Ther Targets 16: 1085-1096, 2012.

119. Chen T, Sun Y, Ji P, Kopetz S and Zhang W: Topoisomerase IIa in chromosome instability and personalized cancer therapy. Oncogene: Oct 20, 2014 (Epub ahead of print). doi: 10.1038/ onc.2014.332.

120. Piccolo S, Dupont S and Cordenonsi M: The biology of YAP/TAZ: Hippo signaling and beyond. Physiol Rev 94: 1287-1312, 2014.

121. Lahusen T, Henke RT, Kagan BL, Wellstein A and Riegel AT: The role and regulation of the nuclear receptor co-activator AIB1 in breast cancer. Breast Cancer Res Treat 116: 225-237, 2009. 